\title{
Meşe Palamudu (Quercus ithaburensis Decne subsp macrolepis) Atıklarının Pleurotus ostreatus Üretiminde Kullanımı
}

\author{
Selim ŞEN, Mesut YALÇIN \\ ${ }^{1}$ Düzce Üniversitesi, Orman Endüstri Mühendisliği Bölümü, 81620 Düzce-TÜRKIYE \\ ${ }^{\star}$ Corresponding author: selimsen@duzce.edu.tr
}

\begin{abstract}
Özet
$\mathrm{Bu}$ çalışma deri sanayisinin önemli hammaddelerinden biri olan meşe palamudunun (Quercus ithaburensis Decne subsp macrolepis) tanen üretiminde değerlendirildikten sonra açığa çıkan atık materyalin Pleurotus ostreatus mantarının üretiminde kullanım durumunun belirlenmesi amacıyla yapılmıştır. Ortaya çıkan atık, içerdiği nem miktarının yüksek olması, kurutma maliyetleri ve nakliye masraflarından dolayı değerlendirilemeyerek işletmelerin sahalarında birikerek, geniş yer işgal etmektedir. Atık olarak temin edilen materyalin kimyasal analizi yapılarak lignoselülozik ortamda yetisen $P$. ostreatus mantarı üretimi için kompostlar hazırlanmıştır. Misel oluşum süresi 45 gün, mantar verimi \%24,5 (yaş ağırlık/taze ağırlık) olarak gerçekleşmiştir. Çalışmanın sonucunda meşe palamudu atıklarının bu mantarın yetiştirilmesinde kompost olarak kullanılabileceği belirlenmiştir.
\end{abstract}

Anahtar Kelimeler: Pleurotus ostreatus, kompost, meşe palamudu atıkları.

\begin{abstract}
Utilizing the Wastes of Valonia Oak (Quercus ithaburensis Decne subsp macrolepis) in Pleurotus ostreatus Production

Abstract

In this study, utilizing the wastes of valonia oak (Quercus ithaburensis Decne subsp macrolepis) in P. ostreatus cultivation is investigated. The tannin obtained from Valonia oak mostly utilized in leather industry. After having been extracted for tannin, the waste has no industrial utilization yet in Turkey. Milled valonia oak wastes composed of acorn cup held high humidity; therefore, has high drying cost for transporting as well as storage problems of the mills. Valonia oak wastes were used as compost to cultivate $P$. ostreatus. Results indicated that the mycelia development on oak wastes were realized 45 days yield of $24.5 \%$ (weight/weight) which is to be considered as potential substrate for $P$. ostreatus cultivation.
\end{abstract}

Keywords: Pleurotus ostreatus, substrate, acorn wastes.

Şen S, Yalçın M (2011) Meşe Palamudu (Quercus ithaburensis Decne subsp macrolepis) Atıklarının Pleurotus ostreatus Üretiminde Kullanımı. Ekoloji 20 (78): 60-65.

\section{GíRIŞ}

Gelişmiş ülkelerde giderek artan tarımsal ve endüstriyel atıkların değerlendirilmesi çalışmaları devam etmektedir. Lignoselülozik bakımdan zengin atık maddelerin en ekonomik değerlendirilme alanlarından birinin kültür mantarı yetiştiriciliğinde kompost hazırlanmasında kullanılması birçok araştırıc tarafindan ifade edilmektedir (Pekşen ve Günay 2009). Kültür mantarcıllğı dünyada süratle gelişen bir sektör olup tüketilen gida maddeleri arasında yemeklik mantarların payı hızla artmaktadır. Kültür mantarına olan talep ile birlikte çeşitli atıkların kompost üretiminde değerlendirilmesi ile ilgili çalışmalar da devam etmektedir. Lignoselülozik esaslı olan bazı atıkların yok edilmesi için yakılması sonucu doğal çevre üzerinde bazı problemler oluştuğu bilinmektedir. Bu atıklar, insan beslenmesi ve sağllğı üzerinde olumlu etkileri olduğu bilinen kültür mantarı üretiminde kolaylıkla değerlendirilebilmektedir. Mantar yetiştiriciliği çevreye dost bir teknoloji olup atık materyallerin oluşturabileceği çevre kirliliğinin önlenmesi yanında mikrobiyolojik degradasyon yoluyla protein değeri yüksek besin maddesi üretilerek dünyada gerekli olan protein açığının kapatılmasına katkı sağlamaktadır (Şen ve ark. 2005a, Akyüz ve Kırbağ 2009).

Kültür mantarcılığ 1 üretiminde Pleurotus türlerinin üretimi dünyada toplam mantar üretiminde üçüncü sıraya yükselerek (Akyüz ve Yıldız 2008) \%24 oranında bir paya sahip olmuştur (Royse 1992). Pleurotus türleri içerisinde özellikle Pleurotus ostreatus mantarı yüksek miktardaki protein içeriği (Baysal ve ark. 2003), yüksek verimliliğinin yanı sıra kolay yetiştirilmesinden dolayı (Chang 2002) dünya genelinde tercih edilmektedir. Pleurotus türleri bulunduğu çevre koşullarına karşı yüksek toleranslı 
olması, inkübasyon aşamasında hızlı bir şekilde misel sarımı nedeniyle birçok lignoselülozik materyal üzerinde fermentasyona gerek duyulmaksızın yetiştirilebilmektedir (Poo-Chow 1980). Ayrıca, bu mantar türlerinin mevsimlere bağlı olmadan yetiştirilebilmesi ve kısa süre içerisinde verim sağlanması üretimine olan ilginin dünya genelinde artmasına neden olmuştur (Ağaoğlu ve Güler 1989). Ülkemizde Pleurotus türleri konusunda birçok araştırma yapılmış olmasına rağmen, henüz az sayıda mantar üreticisi tarafindan ticari olarak Pleurotus türlerinin üretimleri yapılarak piyasaya arz edilmektedir.

Pleurotus türlerinin üretiminde kompost hazırlamada yıllık bitkilerden elde edilen sap saman gibi tarımsal atıklar ve bunların çeşitli karışımları kullanılmaktadır. Literatürde çok çeşitli kompostların bu amaçla kullanılabileceği yer almaktadır. Baysal ve Yalınkılıç (2002) yaptıkları çalışmada ıhlamur ve kavak yaprakları, çam ibresi, odun talaşı, buğday sapı, atık kağıtlar eski gazete kağıtları kullandıkları çalışmalarında kompostların bu mantarın üretimi için uygun olduklarını belirtmişlerdir. Baysal ve ark. (2003) atık kağıtların yonca, atık çay yaprakları ve ot dışındaki, çeşitli odunsu ve otsu atık ve atıklarla hazırlanan yetiştirme ortamlarının, P. ostreatus yetiştiriciliğinde başarılı bir şekilde kullanılabileceği sonucuna varmışlardır. Şen ve ark. (2005a) atık oluklu mukavva, kraft kağıt ve kartonların saman gibi başka bitkisel materyaller ile karıştırılmadan $P$. ostreatus üretimine uygun olduğunu belirtmiştir.

Meşe palamudunun, dünyadaki en geniş yayılışı Türkiye'de olup 260 bin hektar alanı kaplamaktadır (Bozkurt ve Göker 1986). İçerdiği gallik tanenden dolayı (Pelit \%6-10, kadeh \%27,5, tırnaklar ise \% 34-50) ham derilerin sepilenmesinde kullanilan tanen üretiminde değerlendirilmektedir (Anoymous 1991). Meşe palamudu taneni Türkiye'nin ihraç ettiği önemli orman yan ürünleri arasında yer almaktadır. Tanen üretiminde kırıcıdan geçirilmiş meşe palamudu ve kadehleri $80 \mathrm{dk}$ süreyle $80^{\circ} \mathrm{C}$ sıcaklıktaki sıcak su ile ekstraksiyon bataryasında işleme tabi tutulduktan sonra içinden sicak suda eriyen tanen çıkarılmaktadır (Anonymous 2008). Tanenler derilerin sepilenmesinden başka ilaç sanayinde, arıtma sistemlerinde, protein çöktürülmesinde, afyon ve alkol zehirlenmelerinde antidot olarak, ayrıca boyacılık sanayinde kullanılmaktadır (Bozkurt ve Göker 1986, Baytop 1999).

Meşe palamutu (Quercus ithaburensis subsp. macrolepis) kadehlerinden sicak su ekstraksiyonu ile elde edilen tanen çıkarıldıktan sonra geriye $\% 100$ 'den fazla rutubette bir atık kalmaktadır. Türkiye'ye özgü bir sepi maddesi kaynağı olduğu için atıkların en fazla ortaya çıktığı ülke Türkiye'dir (Şen ve ark 2005b). Atık olarak ortaya çıkan bu lignoselülozik ürün diğer kabuk ve talaşların kullanıldığg yerlerde (örneğin tarım sahalarının drenajı ve tarımda malç olarak) aşırı rutubetinden kaynaklanan nakliye sorunlarından dolayı tercih edilememektedir. Bu atıkların yonga levha üretimi, odun briketi üretiminde değerlendirilme çalışmaları devam etmektedir. Günümüzde bu atıklar fabrikalarda enerji sağlamak amacıyla yakılarak tüketilmeye çalışılmaktadır (Anonymous 2008). Nuhoğlu ve Malkoç (2007) atık suların arıtılmasında $\mathrm{Cr}(\mathrm{VI})$ absorpsiyonu amaciyla yaptıkları araştırmalar sonucunda palamut meşesi atığının ağır metalleri gidermede aktif karbona alternatif absorbent olarak kullanılabileceğini belirtmişlerdir.

Ülkemizin yıllık palamut rekoltesi ortalama olarak 60-70 bin ton civarındadır. Palamut kadeh ve tırnaklarındaki \%30-50 oranındaki taneninin çıkarılmasindan sonra teorik olarak 40-50 bin ton civarında atık oluşması mümkün olmaktadır (Şen ve ark. 2006). Bu çalışmada tanen üretiminden ortaya çıkan meşe palamudu atıklarının Pleurotus ostreatus yetiştiriciliğinde kompost malzemesi olarak değerlendirilmesinin uygunluğu araştırılmıştır.

\section{MATERYAL VE METOT}

P. ostreatus mantarının yetiştirildiği materyal olan meşe palamut atıkları Salihli Artu Kimya Palamut İşletmesi'nden temin edilmiştir. Bu atıklar tanen üretimi için hazırlanırken fabrikada $1-4 \mathrm{~cm}$ boyutlarında kırıldıktan sonra $80^{\circ} \mathrm{C}$ de sicak su ile $80 \mathrm{dk}$ boyunca ekstraksiyona tabi tutulmaktadırlar (Anonymous 2008). Atık olarak ortaya çıktığında $\% 100$ den fazla rutubete sahip malzeme fabrika sahalarına boşaltılmaktadır. Su tutma kapasitesi yüksek olan bu materyal kompost hazırlama sırasında süzülüp, sıkılarak fazla suyu uzaklaştırılmıştır. Meşe palamudu atıklarından samanlı ve samansız olmak üzere iki farklı tipte kompost hazırlanmıştır. Çalışmada ayrıca meşe ölü örtüsünün (çoğunlukla meşe yaprağı içerikli) samanlı ve samansız kompostları ile meşe palamutu ve örtü karışımı da denenmiştir. Saman ilave edilen kompostlardaki saman miktarı \%10, kepek ise $\% 5$ oranında kullanılmıştır. pH düzeyinin ayarlanması için \%1,5 oranında kireç kullanılmıştır. Homojen bir karışım elde edilinceye kadar materyaller 
karıştırılmıştır. Toplam 5 farklı özellikte hazırlanan kompostlar \%70-80 rutubete kadar nemlendirildikten sonra 1 er kiloluk miktarlarda olacak şekilde polietilen torbalara doldurulmuştur.

Nemli meşe palamudu atıklarının fabrika sahasında uzun müddet beklemesinden dolayı oluşabilecek bakteri enfeksiyonlarını gidermek için kompostlar buharlı sterilizatörde (otoklav) $121^{\circ} \mathrm{C} \mathrm{de}$ $120 \mathrm{dk}$ süreyle sterilize edilmişlerdir. Otoklavdan çıkarılan kompostlar sıcakken 1 kg'lık polietilen torbalara doldurulmuş, $25^{\circ} \mathrm{C}$ ye soğutulduktan sonra buğgday tanelerine aşılanmış misel ekilerek 25$28^{\circ} \mathrm{C}$ sıcaklıktaki ön gelişme odasına yerleştirilmiştir. Misel gelişmesini tamamlayan kompostlar $5^{\circ} \mathrm{C}$ 'de 2 gün boyunca şoklamaya tabi tutulmuşlardır. Daha sonra nemi \%80-90, sıcaklığı $15 \pm 2^{\circ} \mathrm{C}$ arasında tutulan yetiştirme odasına alınmışlardır (Baysal ve ark. 2003). Günlük 12 saat süreyle 200 lüx şiddetindeki flourensan lambalarla aydınlatma uygulanmıştır (Güler 1988). Hasat işlemi boyunca klimalar yardımıyla oda içerisinde temiz hava sirkülasyonu sağlanırken sıcaklık ve nemin belirtilen değerler arasında kalması sağlanmıştır (Ağaoğlu ve Güler 1989). Yetiştirme odasında hasat dönemi boyunca kompostlardan alınan ürünler tartılarak not edilmiştir. Elde edilen bulgular istatistik programında değerlendirilerek yorumlanmıştır.

\section{BULGULAR}

\section{Kimyasal analiz}

Meşe palamudunun işlem görmemiş numunesi ile tanen üretimi için ekstraksiyona tabi tutulmuş numunesinin kimyasal analizleri yapılarak sonuçlar Tablo 1'de verilmiştir. Tanen üretiminde meşe palamudu sıcak su ile yıkanmaya tabi tutulduğundan antifungal etki gösteren tanenin yaklaşı \% $\% 50^{\prime} \operatorname{sinin}$ yıkanarak uzaklaştığı belirlenmiştir. Kimyasal analiz sonucu meşe palamudunun tanen eldesinden sonra holoselüloz ve lignin miktarlarında bir azalma meydana gelmediği, Pleurotus ostreatus mantarının gelişimi için lignin ve selüloz içeriğinin uygun olduğu belirlenmiştir. Sıcak su çözünürlüğü meşe palamudu atıklarının içeriğindeki tanenli ekstraktif madde oranının \%45,9'dan \%20,8'e indiğini göstermektedir.

Misel Gelişimi: Kompostlarda miselin substratı sarması değişik sürelerde gerçekleşmiştir. Saman içermeyen meşe palamudu kompostlarında misel gelişimi 62 gün, meşe ölü örtüsü (yaprak) kompostlarında 53 gün, ölü örtü +meşe palamudu kompostlarında ise 57 gün sürmüştür. \%10 saman ilave edilen meşe palamudu kompostlarında misel sarım süresi 45 gün, meşe ölü örtüsünde ise 47 günde gerçekleşmiştir. Saman ilave edilmeden hazırlanan meşe palamudu, meşe ölü örtüsü ve bunların karışımlarından hazırlanan kompostlarda misel gelişim süreleri uzun sürmüş, ayrıca miseller zayıf olarak geliştiğinden substratı tümüyle saramamiştır.

Hasat Dönemi: Üretim odasına alınan meşe palamudu kompostlarında basidiokarpların ilk görünmesi 51. gün, ilk hasat 57. günde gerçekleşmiştir. Yaklaşık 40 gün süren hasat döneminde 4 defa ürün alınmıştır. Basidiokarp oluşumunun artık görünmediği kompostlarda 97. gün üretime son verilmiştir. Üretim aşamasında bazı kompostlarda az miktarda görülen küflenme basidiokarpların gelişmesinde çok fazla olumsuz etki yapmamıştır. Hazırlanan karışımlar içerisinden mantar hasadı bakımından en iyi sonucu meşe palamudu atıklarına saman ilave edilen kompostlar vermiştir. Çalışma kapsamındaki beş kompost çeşidinden elde edilen mantar miktarları (taze mantar ağırlığı/rutubetli kompost ağırlığı) yüzde olarak varyans analizi ile karşılaştırılmıştır (Tablo 2).

Kompostlarda hasat dönemlerine göre sağlanan verim miktarları Tablo 3 de \% olarak gösterilmiştir. Her bir kompost grubundan elde edilen toplam mantar miktarının (gram) hasat dönemlerine göre değişimi Şekil 1'deki grafikte belirtilmiştir.

Birinci hasat döneminde diğer 3 hasat dönemine göre en fazla verim meşe ölü örtüsü (MÖÖ) + saman (S) karışımı kompostlardan elde edilmiştir. MÖÖ+S karışımı komposttan toplam mantarın yaklaşık \%49'u ilk flaşta alınmış, ikinci flaşta diğer grupların ikinci flaşlarına göre verimde $\% 50$ oranında bir azalma oluşmuştur. Toplam verimlerinin sırasıyla meşe palamutu artığ (MPA)+saman (S) \%41'ini, MPA \%39'unu, MÖÖ \%38'ini ve MPA+MÖÖ \%37'sini ilk flaşta vermişlerdir. En fazla verimi rutubetli substrat ağırlığına oranla MPA+S karışımı \%24,5 taze mantar verimi sağlayarak göstermiştir. Bunu MÖÖ \%17,6, MPA \%17,1, MÖÖ+S \%15,4, MPA+MÖÖ \%10,9 oranındaki verimlerle takip etmişlerdir.

\section{TARTIŞMA VE SONUÇ}

Meşe palamutu atıklarının ve meşe ölü örtüsünün P.ostreatus mantar üretimine uygunluğu misel gelişim süresi ve yüzde verim miktarları bakımlarından ele alınarak literatürle karşılaştırılmıştır. Yapılan değişik çalışmalarda Pleurotus türü mantarların misel gelişim süreleri 15-30 gün (Khan ve Chaudry 1989) arasında değiştiği bildirilmek- 
Tablo 1. Ekstrakte edilmiş ve edilmemiş meşe palamudu numunelerinin kimyasal analiz sonuçları

\begin{tabular}{|l|c|c|}
\hline Bileşenler & $\begin{array}{c}\text { İşlem Görmemiş } \\
(\%)\end{array}$ & $\begin{array}{c}\text { Ekstrakte edilmiş } \\
\text { (Taneni ç1kar1lmış) } \\
(\%)\end{array}$ \\
\hline Holoselüloz & $64.8 \pm 0.86$ & $66.3 \pm 0.39$ \\
\hline Lignin & $22.6 \pm 0.18$ & $27.4 \pm 0.04$ \\
\hline Kül & $3.00 \pm 0.04$ & $4.72 \pm 0.19$ \\
\hline Ekstraktif madde miktarı & \multicolumn{2}{|c|}{} \\
\hline Alkol - benzen çöz. & $9.60 \pm 0.47$ & $1.63 \pm 0.23$ \\
\hline \%1 NaOH çöz. & $60.7 \pm 0.22$ & $45.3 \pm 0.65$ \\
\hline Soğuk su çözünürlüğü & $39.9 \pm 0.11$ & $14.2 \pm 0.23$ \\
\hline Sicak su çözünürlüğü & $45.9 \pm 0.13$ & $20.8 \pm 0.06$ \\
\hline
\end{tabular}

Tablo 2. Kompost grupları ve flaşlara göre Pleurotus ostreatu verimlerinin karşılaştırılmasına ait varyans analiz tablosu

\begin{tabular}{|l|c|c|c|c|c|}
\hline Varyans Kaynağı & $\begin{array}{c}\text { Kareler } \\
\text { toplamı }\end{array}$ & $\begin{array}{c}\text { Serbestlik } \\
\text { değeri }\end{array}$ & $\begin{array}{c}\text { Kareler } \\
\text { ortalamas }\end{array}$ & $\mathrm{F}$ & $\mathrm{S}$ \\
\hline Kompost grupları & 37803 & 4 & 9450 & 51 & 0.000 \\
\hline Kompostlar^Flaşlar & 140417 & 15 & 9361 & 50 & 0.000 \\
\hline Hata & 51885 & 280 & 185 & & \\
\hline Düzeltilmiş toplam & 230106 & 299 & & & \\
\hline
\end{tabular}

$\alpha=0.05, \mathrm{R}^{2}=0.759$

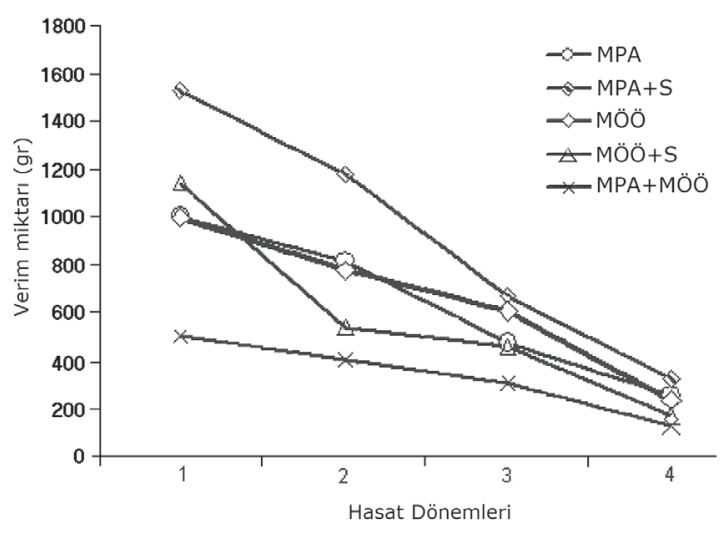

Şekil 1. Kompost gruplarından dört hasat döneminde alınan toplam mantar verimlerindeki değişim

Tablo 3. Kompost gruplarında dört farklı flaşta elde edilen mantar miktarları ve toplam verim yüzdeleri

\begin{tabular}{|l|l|c|c|c|c|c|c|c|c|}
\hline & $\begin{array}{l}\text { Kompost } \\
\text { gruplar1 }\end{array}$ & $\begin{array}{c}\text { Karışım } \\
\text { Oranı }\end{array}$ & $\begin{array}{c}\text { Misel } \\
\text { gel sür }\end{array}$ & \multicolumn{2}{|c|}{ Flaşlar ve hasat miktarları (\%) } & \multicolumn{2}{|c|}{ Verim (\%) } \\
\hline & & & & 1 & 2 & 3 & 4 & $\%^{\star}$ & $\%^{\star \star}$ \\
\hline 1 & MPA+S & $10: 1$ & 45 & 41.22 & 31.83 & 18.13 & 8.82 & 24.5 & 66.3 \\
\hline 2 & MÖÖ & 1 & 53 & 37.95 & 29.70 & 23.12 & 9.24 & 17.6 & 47.7 \\
\hline 3 & MPA & 1 & 62 & 39.12 & 32.00 & 18.49 & 10.40 & 17.1 & 46.2 \\
\hline 4 & MÖÖ+S & $10: 1$ & 47 & 49.35 & 23.25 & 19.82 & 7.59 & 15.4 & 41.7 \\
\hline 5 & MPA+MÖÖ & $1: 1$ & 57 & 37.02 & 30.16 & 22.77 & 10.05 & 10.9 & 25.0 \\
\hline
\end{tabular}

Karışım oranları rutubetli ağırlığa göredir. Misel gelişim süresi (gün), \% verim: * taze mantar ağırlığı/yaş substrat ağırlığına göre verim, $\star \star$ taze mantar ağırlı̆̆1/hava kurusu haldeki (\%12) substrat ağırlığına göre verim.

tedir. Bu çalışmada saman ilave edilmeden hazırlanan meşe palamutu kompostlarında misel gelişimi 62 gün sürmüştür. Kompostlara \%10 saman ilave edildiğinde misel gelişim süreleri kısalarak ortalama 45 gün içerisinde gerçekleşmiştir. Literatüre göre bu misel gelişme süresi de uzundur.
Uzun olmasının bir nedeni olarak meşe palamudu kadehlerinin içerdiği antifungal özellikteki tanenin $P$. ostreatus'un gelişme hızını yavaşlatması söylenebilir. Şen (2001) meşe palamudundan elde edilen tanenin Phanerochaete chrysosporium ve $P$. ostreatus mantarlarına karş1 yaptı̆̆ 1 antifungal araştırmasında, \%4 ve daha üzerindeki tanen konsantrasyonlarının mantar misellerinin gelişimini yavaşlatıcı ve önleyici etki gösterdiğini belirtmiştir. $\mathrm{Bu}$ çalışmada meşe palamut atıklarına saman ilavesinin misel gelişim süresini hızlandırdığı görülmüştür. İlave edilen saman oranı daha da arttırılarak misel gelişiminin daha kısa sürelerde gerçekleşmesini sağlamak mümkün görünmektedir. Güler (1988) buğday samanı üzerinde misel gelişiminin 20-25 gün içerisinde tamamlandığını belirtmektedir.

Meşe ölü örtüsüne saman ilave edilmeden hazırlanan kompostlarda 53 güne varan ve zayıf olarak gerçekleşen misel gelişimi sonucu \%17,6 mantar verimi elde edilmiştir. Çoğunluğunu meşe yapraklarının oluşturduğu ölü örtüdeki bu uzun süren misel gelişimi de yaprakların antifungal özellik taşıyan tanen bakımından zengin olmasının bir belirtisi olabilir. Dollahite ve ark. (1966) meşe ağaç türü yapraklarındaki tanen miktarının \%2-6 arasında olduğunu belirtmiştir. Saman ilave edilerek hazırlanan ölü örtü kompostlarında 47 günde gerçekleşen zayıf bir misel gelişiminin ardından \%15,4 mantar verimi sağlanabilmiştir.

Meşe palamudunun doğal olarak 4,5 olan $\mathrm{pH}$ değeri tannik asidin çıkarılması işlemi sonunda 5,5 civarına yükselmektedir. Kompostlara \%1,5 oranında kireç ilave edilerek pH seviyeleri 5,5-6,5 arasında olacak şekilde ayarlanmıştır. Meşe palamudu atıklarının kimyasal içeriği ve kompostun $\mathrm{pH}$ değerinin mantar üretimine uygun olduğu görülmektedir. Zadrazil (1978) Pleurotus türlerinde 4-8 pH değerlerinin dişında misel gelişmesinin engellendiğini, asidik ortamlarda yavaşladığını bildirmiştir.

Küçükomuzlu ve Pekşen (2005) saman+\%5 kepek $+\% 1$ alçı formülüyle hazırladıkları kompostlarda $P$. ostreatus mantarının hasat sürelerinin 26-54 gün arasında gerçekleştiğini bildirmişlerdir. $\mathrm{Bu}$ çalışmadaki kompostlarda ilk basidiokarpların görünmesi 51. gün, ilk hasat 57. günde gerçekleşerek literatürde belirtilenden daha uzun bir sürede meydana gelmiştir. Yaş kompost ağırlığına göre elde edilen \%24,5 'luk taze mantar verimi literatürle karşılaştırıldığında uygun değerler 
arasında yer almıştır. Chang ve Qumio (1982) Pleurotus mantarlarının üretiminde verim değerinin, yaş substrat ağırlığına oranla ortalama \%30 olduğunu belirtmiştir. Baysal ve ark (2003) atık kağıtt+odun talaşı karışımından hazırladıkları kompostlardan \%36,3, Küçükomuzlu ve Pekşen (2005) saman+\%5 kepek+\%1 alçı karışımından oluşturdukları kompostlarda \%24,6 oranında $P$. ostreatus verimi elde etmişlerdir. Pettipher (1987) çeşitli lignoselüloz esaslı atık maddeleri substrat olarak kullandığı çalışmasında, P. ostreatus için verim değerini yaş substrat ağırlığına oranla \%25 olarak bildirmiştir. Erkel ve Işık (1992) P. ostreatus'un çeltik sap1 üzerinde verim değerini $\% 16,8$, buğday sap1 üzerinde \%11.4, mısır sapı üzerinde \%15,5, ayçiçeği sapı üzerinde \%10,7 olarak bildirmişlerdir. Yıldız ve Demir (1998) çeşitli bitkisel artıklar üzerinde $P$. ostreatus'un verim oranlarına ait araştırmasında yer fistığı sapında \%24,8, soya sapında $\% 21,9$, buğday samanında \%17,5 ve sorgum sapinda \%11,4 oranında verim elde ettiğini belirtmiştir. Baysal ve ark (2003) atık kağıt ve odun talaşı (3:1) kompost karışımı üzerinde yaş ağırlığa oranla \%36.3 P.ostreatus verimi elde etmişlerdir.

Meşe palamudu atıklarından hazırlanan kompostlar üzerinde misel sarım ve basidiokarp oluşum zamanlarının literatüre göre biraz uzun olmasına rağmen, elde edilen mantar verimi bu atıkların $P$. ostreatus mantarının yetiştiriciliğine uygun olduğunu göstermektedir. Meşe palamudu atıklarının kabuk ve talaş gibi enerji maksatlı olarak odun briketi yapımında, tarımda toprak ıslahında ya da malç olarak kullanılması da mümkün olabilir. Su tutma özelliğinin fazla olmasından dolayı uzun süre nemli kalabilen atıkların fabrika sahasından başka bir yere nakliyesinin masraflı olması yanında diğer taşıma güçlükleri de oluşabilmektedir. $\mathrm{Bu}$ çalışmanın sonuçlarına göre meşe palamudundan (Quercus ithaburensis) tanen üretiminden sonra arda kalan ve fabrika sahalarında biriken nemli atıkların işletmelerde kurulacak bir ilave tesis ile Pleurotus ostreatus yetiştiriciliğinde değerlendirile-bileceği belirlenmiştir. Bu tesis meşe palamudu atıklarından oluşan çevre sorunlarının azaltılması yanında, istihdam ve gelir sağlamak için olanaklar da oluşturabilecektir. Meşe palamudu atıklarının Pleurotus ostreatus mantarının yetiştiriciliğinde kullanılabilirliği ile ilgili bu çalışma bir ön çalışma niteliğindedir. Daha detaylı çalışmalarla atıkların kompost üretiminde değerlendirilebilmesi için en ideal karışımların belirlenmesi gerekmektedir.

\section{KAYNAKLAR}

Ağaoğlu YS, Güler M (1989) Yenilebilir Mantar Yetiştiriciliği. Orman Genel Müdürlüğü Yayınları, Ankara.

Akyüz M, Yıldız A (2008) Evaluation of cellulosic wastes for the cultivation of Pleurotus eryngii (DC. ex Fr.) Quel. African Journal of Biotechnology 7 (10): 1494-1499.

Akyüz M, Kırbağ S (2009) Bazı tarımsal ve endüstriyel atıkların Pleurotus spp. üretiminde kompost olarak değerlendirilmesi. Ekoloji 18 (70): 27-31

Anonymous (1991) Ülkemizdeki bazı önemli orman tali ürünlerinin teşhis ve tanıtım kılavuzu. Orman Genel Müdürlüğü Yayınları Yayın No:659-18, Ankara.

Anonymous (2008) Meşe Palamudu Üretimi. Artu Kimya Palamut İşletmesi teknik dökümanları, Salihli, İzmir.

Baysal E, Yalınkılıç MK (2002) Lignoselülozik atık materyal üzerinde Pleurotus florida Jacq. ex Fr.Kumm. kültürü. Ekoloji 11 (45): 6-8.

Baysal E, Yalınkılıç MK, Peker H, Çolak M, Göktaş O, Özen E, Çolak AM (2003) Atık kâğıtların çeşitli bitkisel ve odunsu atık substratlarla Pleurotus ostreatus Jacq. ex Fr. Kummer kültivasyonunda değerlendirilmesi. Ekoloji 12 (49): 12-16.

Baytop T (1999) Türkiye'de bitkiler ile tedavi. Nobel Kitabevi, İstanbul.

Bozkurt Y, Göker Y (1986) Orman Ürünlerinden Faydalanma Ders Kitabı. İstanbul Üniversitesi Orman Fakültesi Yayın No: 3402-379, İstanbul.

Chang ST, Qumio TH (1982) Tropical Mushrooms, Biological Nature and Cultivation Methods. The Chinese University Press, Hong-Kong.

Chang ST (2002) Past and present trends in the production of Lentinula edodes in Asia. In: Sanchez JE et al. (eds), Proceedings of the $4^{\text {th }}$ International Conference on Mushroom Biology and Mushroom Products, 20-23 February 2002, Cuernavaca, 1-8. 
Dollahite JW, Householder GT, Camp BJ (1966) Oak poisoning in livestock. Texas Agricultural Experiment Station Bulletin, No: B-1049, Amarillo.

Erkel İ, Iş̧1k SE (1992) P. ostreatus ve P. florida yetiştiriciliğinde değişik yetiştirme ortamlarının verime etkisi. In: Türkiye 4ncü yemeklik mantar kongresi bildirileri, 2-4 Kasım, Yalova, 121-126.

Güler M (1988) Kayın Mantarı Yetiştirme Tekniği. Orman Genel Müdürlüğü Yayınları, Yayın No: 669-16, Ankara.

Khan SM, Chaudhary C (1989) Some studies of oyster mushroom (Pleurotus spp.) on the waste material of corn industry in Pakistan. In: Proceedings of the $12^{\text {th }}$ International Congress on the Science and Cultivation of Edible Fungi, Braunschweig, 23-29.

Küçükomuzlu B, Pekşen A (2005) Yetiştirme ortamı ağırlıklarının Pleurotus mantar türlerinin verim ve kalitesi üzerine etkileri. Ondokuz Mayıs Üniversitesi Ziraat Fakültesi Dergisi 20 (3): 64-71.

Nuhoğlu Y, Malkoç E (2007) Cr(VI) iyonunun gideriminde palamut meşesi atığının kullanımı. In: 7. Ulusal Çevre ve Mühendislik Kongresi-Yaşam ve Çevre, TMMOB Çevre Mühendisleri Odası, 24-27 Ekim, İzmir, 669-675.

Pekşen A Günay A (2009)Kültür mantarı (Agaricus bisporus (L.) Sing.) yetiştiriciliğ̈inde çay atığı ve buğday sapı karışımından hazırlanan kompostların kullanımı. Ekoloji 19 (73): 48-54

Pettipher GL (1987) Cultivation of oyster mushroom (Pleurotus ostreatus) on lignocellulosic waste. Journal of the Science of Food and Agriculture 41, 259-265.

Poo-Chow L (1980) Utilization of cotton waste substrate wiith temperature treatment for the cultivation of oyster mushroom (Pleurotus ostreatus). Singopore Journal of Primary Industries 8-1, 21-27.

Royse DJ (1992) Recycling of spent Shii-take substrate for production of the Oyster mushrooms Pleurotus sajor-caju. Applied Microbiology and Biotechnology 38, 179-182.

Şen S (2001) Bitki fenollerinin odun koruma etkinliklerinin belirlenmesi. Doktora Tezi, Zonguldak Karaelmas Üniversitesi Fen Bilimleri Enstitüsü, Zonguldak.

Şen S, Çöpür Y, Taş̧̧ığlu C, Akgül M (2005a) Atık kraft kağıtlarının Pleurotus ostreatus üretiminde kullanımı. In: I. Uluslararası Çalıştay - Kağıt ve Karton Endüstrisinde Yeni Teknolojiler, Kahramanmaraş. 28-29 Eylül, 122-127.

Şen S, Deniz İ, Şahin Hİ (2005b) Sepi maddesi eldesinde önemli odun dışı ürünlerimiz, üretimleri ve kullanımları ile ilgili sorunlar ve çözüm önerileri. In: 1. Çevre ve Ormancılık Şurası "Tebliğler", 3. Cilt, Mart 2005, Antalya. 1184-1197.

Şen S, Deniz İ, Hakimoğlu İ, Tırak K, Gültekin YS (2006) Meşe palamudundan sepi maddesi üretimi karşılaşılan sorunlar ve çz̈züm önerileri. In: 1. Uluslararası Odun Dışı Orman Ürünleri Sempozyumu Bildirileri, 1-4 Kasım 2006, Trabzon, 806-811.

Yıldız A, Karakaplan M, Aydın F (1998) Studies on Pleurotus ostreatus (Jacq. Ex Fr.) Kum. var. salignus (Pers. Ex Fr.) Konr. et Maubl. Cultivation, Proximate Composition, Organic and Mineral Composition of Carpophores. Food Chemistry 61 (1/2): 127-130.

Yıldız A, Demir R (1998) Bazı Bitkisel Materyallerin Pleurotus ostreatus (Jacq.ex.Fr.) Kum. Var. Salignus (Pers. Ex.Fr.) Konr.et Maubl.'un Gelişmesi ve Ürün Verimi Üzerine Etkileri. Turkish Journal of Biology 22, 67-73.

Zadrazil F (1978) Cultivation of Pleurotus. In: Chang STC, Hayes WA (eds), The Biology and Cultivation of Edible Mushroom, Academic Press, New York, 521-554. 